Article

\title{
Transcendence Un-Extra-Ordinaire: Bringing the Atheistic I Down to Earth
}

\author{
Nathan Eric Dickman \\ Department of Religion and Philosophy, Young Harris College, Young Harris, GA 30582, USA; \\ nedickman@yhc.edu
}

Academic Editor: Justin Sands

Received: 13 November 2016; Accepted: 23 December 2016; Published: 30 December 2016

\begin{abstract}
I examine challenges to images of a personal god definitive for normatively policed theism (often called "traditional theism"), questioning whether a subject can be conscious of a transcendent being. I examine the challenges to show that disappointment with such images calls for rethinking terms like "transcendence" in horizontal rather than vertical registers. Through this, I indicate an irony in yearning for transcendence, one in which there is movement toward-rather than beyond-the utterly ordinary. We will see that such un-extra-ordinary transcendence makes a difference once difference is no longer determined under the hegemony of what Levinas calls "the atheistic I." I bring together resources from feminist philosophies and Asian religions both to elaborate on the nature of the atheistic I and to rehabilitate a redeeming appreciation of the ordinary. My hope is to ameliorate disempowered estrangement by indicating ways the ordinary generates, not inhibits, becoming. However, my broader intent is to contribute to shifting sands in contemporary philosophy of religion due to recent calls for diversifying the field by including multiple religions, questioning the centrality of belief, and engaging multiple methods relevant in religious studies.
\end{abstract}

Keywords: traditional theism; transcendence; Levinas; Irigaray; Feuerbach; metaphor; Ricoeur; Zhuangzi; semantics; the ordinary

Why do we assume that God must always remain an inaccessible transcendence rather than a realization-here and now-in and through the body?

Irigaray ([1], p. 148)

The modern subject, the "I", finds itself estranged from one's self and body, one's world and others in it, one's language and nature itself. Levinas calls the modern subject's self-enclosed system of estrangement "the hegemonic and atheistic I" ([2], p. 222). Alone, the atheistic I constitutes its world without the possibility of metaphysical transcendence or connection, stuck in a stubborn solipsism. If the I is all there is, then there seems to be no transcendence. Levinas thinks this temptation of the I toward atheistic solipsism results from being struck by the idea of the infinite. Levinas emphasizes the affective quality of perceiving the infinite in his analysis of Descartes's meditator's cosmological argument for the existence of a god. The infinite cannot be cognitively grasped because it exceeds any concept a finite thinker can formulate for it. Thus, knowledge of the infinite-as a mental representation corresponding to mind-independent objects—cannot be realized ([3], p. 84). Instead, the infinite is felt. The meditator is, in Levinas's words, "bedazzled" by the infinite [2]. The experience is overwhelming, and it either rouses the "finitude of being" - the I, consciousness-to responsible service for others, or wounds one to withdraw into the atheistic I. In other words, feeling the infinite, one either dilates toward a "transcendent" connection with others or contracts to solipsistic enclosing without possibility for transcendence.

The atheistic I's stubborn solipsistic immanence makes realizing transcendence seem impossible to the I, as if either possessing something transcendent or absorption into something transcendent 
exhausts our spiritual potential. Both feeling deprived of transcendence in solipsistic immanence, and-perhaps worse- believing one is connected to a transcendent entity misinterpret "transcendence," according to Levinas ([2], p. 222; [4], pp. 71-73). Why is it difficult to interpret? As I develop, there are two orders of transcendence: as imagined by the atheistic I, and as realized by the finitude of being opened to sociality (see [2], p. 222). In light of this distinction, I unfold one way transcendence may be otherwise than what the atheistic I anticipates it to be. ${ }^{1}$ I explore "the ordinary" to consider just how otherwise transcendence may be. Perhaps the eschaton is the ordinary, that which the atheistic I takes as merely banal or mundane?

The procedure I undertake is as follows. First, I develop three challenges to presuppositions about transcendence in normatively policed Christian theism. Second, I provide a semantics of metaphor to think otherwise about transcendence, situating it within what I call "the poetic redemption of the real." Third, I shed light on the ordinary as an eschaton, as that which might fulfill existential transcendence, in order to bring the atheistic I down to earth and to explore potential areas for further research. ${ }^{2}$ I seek to contribute to shifting sands in contemporary philosophy of religion due to recent calls for diversifying the field by including multiple religions, questioning the centrality of belief, and engaging multiple methods relevant in Religious Studies (see [11]).

\section{Challenging Normative Theism}

No one can secure themselves from succumbing to the hegemony of the atheistic I simply through social identification with a religion. Indeed, it may be tempting especially for religious practitioners to believe they have overcome the atheistic I's self-enclosure. They identify with a religious community, argue for beliefs, revise doctrines, practice rituals, perform service, and feel fulfilled. ${ }^{3}$ Yet, even the most nominal participants in religions are sensitive to idolatry and heresy. Many not only see the "wrong" religions as ultimately vacuous, but also see members within their own communities as merely "going through the motions" or hypocritical. Further still, the most sophisticated of philosophical theologians may misrecognize already succumbing to the atheistic I, despite protests to the contrary. In this section, I show a way this is the case for participants debating in the orbit of so-called "traditional theism." I examine three challenges to images of a personal god definitive for normatively policed Christian theism, challenges that turn to the subject who thinks of one's god. The challenges clarify characteristics of the atheistic I operative in normatively policed theism. At stake is not if a thinker has justified belief in or rejection of a transcendent entity's existence. Instead, at stake is the I's desire for and conception of a peculiar kind of transcendence.

Much of contemporary philosophy of religion and philosophical theology is merely normatively policed Christian theism. In these disciplines, "religion" is approached predominately as synonymous with—or at least oriented by-Christian accounts of the divine [11,13]. It is so concentrated that

1 I do not have any pretense to be doing something new or novel in this. I recognize the effort of reconceptualizing transcendence, or concepts in general, is extremely widespread and I recognize there are countless movements undertaking such effort. I want to contribute from a hermeneutic and phenomenologically informed perspective. Yet I want to keep my proposal relevantly distinct from projects that seek to develop a notion of transcendence informed by "immanence" as most phenomenologically informed projects do, such as Nancy's notion of "transimmanence" as Verhoef develops it in this special issue of Religions (see [5]). I am not against such projects, by any means, and I hope my proposal here is compatible with them, just as I hope my proposal is compatible with Levinas's phenomenologically informed approaches to rethinking transcendence as ethics. I merely wish to focus on "the ordinary" as that by which transcendence is usually and conventionally defined-that transcendence is primarily about somehow getting beyond ordinary circumstances. See the first paragraph in Section 3 below for more detail. I am also aware that there are numerous contemporary movements rethinking ideas as part of our natural world, such as emergence theory (see [6]) and the new materialisms (see [7,8]), as well as numerous classical philosophical or religious immanent frames, such as Spinoza's pantheism, Epicurean atomism, and the historical Buddha's dependent arising. My personal favorite is Gadamer's reading of Plato as the first "anti-Platonist" (see [9]). I note all this to indicate as thoroughly as possible that I have no pretense to thinking my contribution is completely new or novel. If I merely amplify something Zhuangzi or Irigaray or Levinas has said, I feel that is accomplishment enough.

2 I draw the point about bringing the atheistic I "down to earth" from Berling's study on classical Chan (see [10]).

3 Feelings, beliefs, and practices may be distortions of faith rather than instances of it. Tillich distinguishes between intellectual, emotional, and volitional distortions of faith ([12], pp. 35-46). 
accounts are called, more generically, "traditional theism." ${ }^{4}$ Most who are familiar with philosophy of religion know what to expect from descriptions of "the traditional concept of God." This concept typically includes a number of properties of perfection-such as omniscience, omnipotence, omnibenevolence, having no body and standing apart from the universe, and so on. Moreover, these properties coalesce in one personality ([14], p. 22; [15]). Further still, this god is said to have power over nature through language, deploying discourse for control more than understanding (see [16], p. 43). This god, then, seems to be a "transcendent self-sufficient monarch" ([17], p. 144)..$^{5}$ It possesses the one exclusively true perspective, and to align oneself with it through personal commitment is to gain epistemic privilege of access ("revelation") to this perspective (see [19]).

This concept appears traditional because it seems to have dominated varying histories of Greek influenced Christian thinking about the divine, and-through patent isegesis-is often said to have "biblical" roots (see [17], p. 144). What is the function of the word "traditional" so qualifying various accounts of a god? It shores up institutional power to give a present description of a god an aura of transhistorical authority, a uniformity and consistency above cultural and historical particularity. It is not that a specific conception has in fact been dominant and so gets called traditional; it is that a specific conception at stake seems to have been dominant because it is called traditional in the present. Apologist guardians police discourse in philosophy of religion through boundary-making and boundary-preserving uses of the term. ${ }^{6}$ Even with revisionists like Hick or Schilbrack, their use of the term inadvertently reinforces normatively policed Christian theism's institutional hegemony over philosophy of religion. ${ }^{7}$ While some might propose an alternative edgy concept, such as Rubenstein's appeal to tzimtzum in his proposal of the "Holy Nothingness" [22], it is only the edge of a continent over which traditional theism purportedly holds dominion.

This use misrecognizes the meaning of "tradition," and so we know it is solely bullying to perceived outsiders and policing uniformity of discourse. A tradition is a complex historically evolving phenomenon, determined by an interplay of both innovation and sedimentation ([24], p. 125). ${ }^{9}$ The word "tradition" gets at a historical phenomenon defined by conventions and contextual contingencies within which sedimentation and innovation occur, and is not a term for denoting a transhistorical entity unaffected by history. To call this or that a tradition constructs a history, highlighting an expediently relevant past while orienting anticipation for a preferred and expected future. When the scholar of religions reinscribes "tradition" in their own scholarship, deference is paid to the interests of religious institutions and their telling of "history," rather than dealing with the laborious work and messiness of genealogical historicism. ${ }^{10}$ Because of this, any deployment of "traditional" as a qualification of some presently articulated account of the divine is to police the boundaries of what or who is inside and

4 The phrase is shared across loyalties in Western philosophical theologies, from conservative apologists such as Craig and Plantinga and Swinburne to revisionist critics such as Hick and Hare and Oakes to advocates for atheism such as Rowe and Smart and Harris.

5 And this god is often identified with the unity of "Being" itself (see [18], p. 70).

6 Is this not just the hunt for heretics in new clothes? By virtue of policing what is or is not traditional, guardians determine who is in and who is out, not what is or is not "the" traditional concept of a god. Does Deloria's notion of a "red" god count [20]?

7 For an analogy, see Adorno's critique of jazz where he illuminates that jazz's syncopation inadvertently reinforces rather than overcomes uniformity of rhythm [21].

8 Jonas also appeals to medieval kabbalistic Judaism in his development of a notion of a suffering god [23].

9 See also $[25,26]$. That dialectic is readily observed in evolutions of musical performance. Each occasion in which a musical score is performed changes the being of the piece. Each occasion is affected by contingent circumstances, from the acoustics of the space to the quality of the instruments to the skill or talent of the performer. But in some instances, these factors coincide in a performance that sets a new standard for the tradition of interpreting the piece. In popular music, this sometimes happens when a cover of a song seems to capture the essence of the song more than the original version itself.

10 Here I am thinking in particular of McRae's thorough analysis and criticism of the "string of pearls" tradition in Transmission of the Lamp "recorded sayings" literature in the constitution and construction of the Chan (Zen) transmission lineage (see [27]). Despite the Zen tradition's telling of its own history, the one smoothing out the revisions into a pristine transmission of the dharma from heir to heir, we know from the Dunhuang cave manuscripts that texts such as the Platform Sutra attributed to Huineng went through numerous editions and revisions. By analogy, this applies to any traditions' telling of its own history. For example, is Moses really the author of the Torah? Is Mark really the author of the "second" Gospel? The "tradition" of 
outside legitimate discourse about the topic. Conservative uses make it appear as if history is on their side when that is not so; progressive uses of the phrase as a target of criticism make it appear as if critics are more advanced than they probably are. In other words, the usage serves the current interests of the subject who thinks with-or against-a purportedly traditional concept. ${ }^{11}$ There is no concept of a god that has been dominant throughout variegated global human histories, however much it might be predominate in the contemporary Christian influenced philosophy of religion publication industry. ${ }^{12}$ Thus, spending time identifying what is or is not the traditional notion of a god is shadow-boxing, establishing social hierarchies like those dwelling inside Plato's cave. I underscore this to help us turn around to examine the I so investing its time this way. At issue is not some entity to which a mental representation (in)adequately corresponds, but us-the subjects thinking a concept and our need for our concept to align with or go against tradition.

Focusing on one's god as if it were the traditional one deflects attention away from the I for whom this god is an issue right now. Why does the I deflect attention away from itself? More than the psychology of denial is relevant for explanation here. As we know from phenomenology, the glacial drift toward the object pole of consciousness is a function of doubling within the structure of subjectivity itself (see [28]). ${ }^{13}$ The origin point of thinking is systematically elusive to consciousness. The "ego" is, as Sartre explains, transcendent to consciousness [31]. When we think about ourselves, we can never think about the active thinker, but only always what the thinker is thinking about. In this way, consciousness of subjectivity divides into the poles of what we can call the "I" and the "me" [28]. What is significant is that in this light, we recognize the constitutive role the I plays in determining the being of what it thinks about. ${ }^{14}$ The I conceptualizes what it thinks. ${ }^{15}$ The important question to ask is what interest such conceptualization of a god as "the traditional" one serves for the I. What is the

speaking about "traditional theism" itself has its own genealogy and revisions and editions and disruptions detectable via proper historicist methods.

11 To what end do I need to show my concept of my god is consistent with some apparent traditional notion? To what end do I need to show my denial of the existence of some god is a denial of some seeming traditional notion?

12 There are numerous contemporary contextual features left insufficiently addressed in recent philosophy of religion. It downplays or entirely omits complex differences among groups and individuals identifying as religious, particularly cultures with distinctive religious histories. For example, does "the traditional concept of God" include how ancient Indians conceived of Brahman? Or is Brahman obviously excluded from traditional theism? Why ought any reasonable thinker subscribe to that-even if it is the current (normative) convention? Moreover, what about the stark diversity throughout the histories of Greek influenced theisms themselves-such as mystic approaches to the divine with Isaac Luria or Margery Kempe? Further still, in most instances of philosophical reflection about religion, relevant distinctions are made between a folk theology of the community and philosophically informed theology-such as with Ibn Rushd and Maimonides. Are lay conceptions of a god excluded from what purportedly dominates intellectual history?

We can also emphasize how each individual or community responds to historically local issues in their accounts of the divine, which indicates historical conditions disrupt continuity as much as facilitate continuity. For example, the medieval theologians influenced by Aristotle were peculiarly concerned about the question of the world's eternity-indeed, Maimonides went so far as to say that unless the Creation could be firmly established against Aristotle's theory of the eternity of the world there was no point in maintaining commitment to his Judaism. Medieval accounts of the divine are always developed relative to this specific issue of the world's eternity, an issue of little to no relevance in accounts in the West today. When a contemporary thinker calls this or that description of a god the "traditional" one, it suggests that what's described is the same as that developed by Aquinas or Muhammad or Paul. This is simply not so, and to think it is so is to lack awareness of history.

13 See also ([29]; [30], pp. 316-77).

14 This is the superiority of varying phenomenologies over earlier empiricist or even rationalist metaphysics: it is reflexive whereas both of the latter are merely reflective. See [32].

15 However, this is not to dismiss the traditional concept of a god as a mere social construct. In the last century, both "social construction of reality" in sociology and "deconstruction" in philosophical hermeneutics emerged as critical concepts in exposing what seems artificial, flexible, and revisable. The accusation abounds that as diverse of things from race, gender, and disability to climate change, death, nature itself are all merely "socially constructed" (see [33,34]). Yet, if we are not careful in our application of this criticism, we may be led to believe there is some realm of what is not constructed and that cannot deconstruct, some reality that transcends human categorizations. Obviously, even if race and gender are "mere" social constructs, that does not diminish their actual repercussions throughout our histories. Cultural phenomena are not somehow unreal and revisable in comparison with natural phenomena that are somehow factual and irrevocable. This applies just as much to our notion of "traditional theism" or "the traditional concept" of a god. The impact of the I precedes the difference between the revisable and the irrevocable (see [35], pp. 283-91). Merely exposing traditional theism's constructedness is, then, insufficient. 
nature of the subject for whom traditional theism is at stake? I am interested in three key challenges to the I's naiveté as it rests contentedly in traditional theism. ${ }^{16}$ These challenges clarify characteristics of the atheistic I.

My first challenge centers on existential projection (see [14,37]). Subjective ideals and projects are taken as sentential subjects referring to things "out there." Through imagination, as Feuerbach explains, we make our ideals into entities distinct from ourselves, as divine beings ([14], pp. 22-23). This reification alienates humans from their gods, where gods are constructed as radically different from us. In this way, the I escalates ordinary existential transcendence into a metaphysically transcendent entity. We misrecognize such impact of the I through inverting grammatical subjects and predicates. What are properly predicates are used as names. Indeed, language itself is interpreted as essentially naming-to the point where naming seems like an occult process. ${ }^{17}$

To illustrate: Many Buddhists today refer to the historical Buddha in the abbreviated form of "Buddha," as if it is a proper name (see [38]). However, that honorific is not the historical Buddha's name. ${ }^{18}$ By comparison, contemporary Christians often call Jesus of Nazareth "Christ." However, obviously that is not Jesus' last name (see [39], p. 97). The same applies to the word "god." The word "god" is not a name. ${ }^{19}$ Yet, many today expediently refer to their deity simply as "God." Indeed, some uninformed Americans fear Muslims because they purportedly worship a "false" and different god named "Allah." ${ }^{20}$ In the effort to respect the sacredness of their god's name, many contemporary Jews replace the letter "o" with a dash when writing the word, as in "G-d." However, just as Marduk is a high god in Mesopotamian mythology, the tetragrammaton signifies the personal name of the god of Jewish religious texts. Words like "buddha," "christ," and "god" modify the subject of which they are predicated, like the word "hero." There is obviously something grammatically off with the question "Does 'hero' exist?" Asking if "god" exists is the same. This is especially troubling in philosophy of religion, and the litany of arguments for or against the existence of a god. Which "god," exactly? Yet, arguments for (or against) the existence of the so-called traditional god are taken so seriously that a publication industry surrounds it and the theme normatively defines the discipline. ${ }^{21}$ The word "god" is a "predicament," 22 not a subject. Thus, "god" is never personal. ${ }^{23}$ Yet, a person may be given the honorific of being called "god." The mystery of "god" is not really in the entity named, but in the copulating relation between a subject and such a predicate.

It is no wonder many theologians deny positive predicates apply to this supposed entity. It is not because the divine entity transcends human conceptualization, but because predicates properly apply

16 What is it about the I that it would produce such a concept? In whose interests is it? I am not here asking about political or economic interest, but ontological interest-in preserving a kind of being. Even more challenges can be developed, though, such as Western imperial hegemony. On this, see [36].

17 As Ricoeur writes, "Although naming is an important 'language game,' the overestimation of the word and even fascination with words, pushed to the point of superstition, reverence, or terror, are due perhaps to a basic illusion...that the naming game is the paradigm of all language games" ([35], p. 150).

18 As far as we can tell, his family name was Gautama, and over time various communities ascribed the legendary name "Siddhartha" to him.

19 Against Caputo (see [40]). While in function, it might serve expediently as a name, as noted above with "Buddha," this abbreviated way of speaking misses the gap (or predicative link) between the office a person holds and the particular person's actual name. This will be further elaborated below.

20 As we know, "Allah" is just Arabic for "the god" (see [41]). But this is not always kept sufficiently clear, even in informed scholarly work. See, for example, Simmons and Sanders, where they write, "The 'God' of a theology of absence is the 'tout autre' (i.e., the absolutely other), not Jesus, Allah, or Yahweh, for such names are already too determinate, too constrained, and too final" ([40], p. 39). Here "Allah" is listed among personal names, giving it the aura of a personal name.

21 As Tillich describes them, such arguments are "meaningless" ([12], p. 53).

22 As Muller and Weigelt translate Kant in naming fundamental categories ([30], p. 106). He calls derived concepts "predicables." I think they should be reversed: a "predicable" is that of which one is able to predicate, that is, objects as they are synthesized out of the manifold via fundamental categories. A "predicament," alternatively, is that situating of a predicable in an intelligible context. Of course, Kant himself reserves the word "god" for one of the three ideas of pure reason. I hope to address all this at another time in further research.

23 In response to Simmons ([43], pp. 41-42). 
to sentential subjects-not to other predicates. ${ }^{24}$ The inversion of subject and predicate generates illusions, an illusion of another world behind this world. In seeking transcendence under this illusion, we are-as Feuerbach and Nietzsche differently clarify—desiring nothingness, willing nonbeing (see [44]). It is not merely that we seek a better world beyond the ordinary one. Feuerbach writes,

In the inmost depths of thy soul thou wouldest rather there were no world, for where the world is, there is matter, and where there is matter there is weight and resistance, space and time, limitation and necessity. Nevertheless, there is a world, there is matter. How dost thou escape from the dilemma of this contradiction? ... Certainly the act of creation does not suffice to explain the existence of the world or matter, but it is a total misconception to demand this of it, for the fundamental idea of the creation is this: there is to be no world, no matter; and hence the end is daily looked forward to with longing ([14], p. 110, my emphasis). ${ }^{25}$

The fundamental ideas of creation and apocalypse are not merely symptoms of the wish that there be no world, though. To go one step further: for the atheistic I, there already is no world. The atheistic I is alone without being lonely because there is no other for it to miss. The desire for a kind of transcendence to a transcendent place or to a relation with a transcendent entity plays a corrupting role in taking an object as the absolute rather than as symbolic for existential transcendence. ${ }^{26}$

My second challenge focuses on patriarchy, specifically a feminist critique of masculine subjectivity (see, for example, [45]). The orientation toward solipsistic domination is in part also a function of patriarchy. A utilitarian stereotype of "the Other" rests at the heart of patriarchal Western philosophy, according to Anderson ([13], p. 197). As Irigaray explains, the male subject defines gender by subordination and exclusion of the female subject. Anderson elaborates, "Man creates his gender in relation to projection of the self-same subject" ([13], p. 197). The obsession with naming or labeling is peculiar to masculine subjectivity's interest in sameness. Language is reduced to an instrument of fortification and mastery, for organizing knowledge and ordering society around it. It idolizes words as mere names, presupposing "the One," one truth and one perspective on that truth. It strives for a perfectly exact language to name reality. ${ }^{27}$ Men's understanding and wisdom promotes agreement through sameness, destroying alterity by reducing others to the logic of the same ([46], pp. 34-40). Speech merely transmits rather than reciprocates, in idle-talk which everyone can snatch up and which divests speakers of the task of understanding (see [37], p. 161). In this way, masculine subjectivity develops a dispassionate and distanced objectivity, an indifferent intelligibility from which nothing is closed off from taxonomic labeling ([37], p. 158). For this sort of subject, language is experienced as a prison where labels always get between one and pure reality in itself ([46], p. 34).

Reification of the divine into an alien entity is distinctively male, according to Irigaray ([44], pp. 104-20). ${ }^{28}$ The masculine subject looks for difference or transcendence in the wrong spaces, where one wonders if there is life on other planets rather than right next to one in the same house. The masculine subject looks vertically to the skies for salvation from aliens and gods. Moreover, the

24 Feuerbach goes so far as to call this denial of positive predicates to the traditional god "atheism." While a concept can be defined and refined, and in doing so will be the subject of many sentences, we do not have to confuse defining words with actually saying something about something. No one tries to read the dictionary for its plotline (yet, anyway).

25 Think of the popularity of the end of the world theme in film, and the apocalyptic preaching in American evangelistic Christianity.

26 It distorts our perspective by turning it in on itself and into the wish that we alone exist, that the subject alone exists-an aspiration to be the complete and self-sufficient unconditioned whole (see [13]). I qualify transcendence with "existential" in order to indicate that there are plenty of sorts of transcendences, but just not metaphysical ones. The prefix "trans-" indicates a movement beyond, and the root word "-scend" means to climb. Just as many people regularly ascend stairs, so do they regularly transcend varying existential dynamics, such as through projection of possibilities by which they can imagine climbing beyond their present circumstances?

27 Drawing inspiration from Leibniz, this effort culminated in the attempt at and abandonment of Esperanto.

28 Whereas Feuerbach calls for recognition of the illusion generated by imaginative projection in order to overcome alienation, Irigaray seems to call on women to project for themselves even despite the drift toward illusions (see [13]). 
masculine subject defines himself as a subject in this abstract and illusory metaphysical world, and so "nature" is also already abstract from lived embodiment ([16], p. 96). The illusory world no longer corresponds to the natural universe. For Irigaray, without properly situating ourselves in this world without reference to a non-abstract nature, we oscillate between the extremes of mere abstractions without anchorage in our own natures or as regressions to sheer animality ([16], p. 96). Rooted in an absolute and universal perspective, this exposes the gendered character of the Ifor whom traditional theism is an issue. ${ }^{29}$

While only the male and his god are subjects in contemporary discourse, women do possess the power to reverse subject and predicate ([18], p. 67). For Irigaray, women are in need of their own subject and predicate, their own elemental sentence by which to articulate their existential transcendence, which would require bringing words down from abstraction. In guiding others to this power, she asks, "Is God sick in never being married?" ([18], p. 70). She seems to ask this in a playful way in order to undermine the neutered abstraction of masculine subjectivity. This is not the sort of question typically considered in debates surrounding "traditional theism." Why repress sensible faculties for a "hypothetical beyond" such as a reified heaven or nirvana? Why diminish the ordinary for a hypothetical and abstract transcendent? The atheistic I is both nihilistic and patriarchal. What makes it "atheistic"?

My third challenge focuses on Levinas's identification of the intrinsic atheism of the modern subject's conceptualization of thinking itself ([2], p. 222). Knowledge and answers are determined by the correspondence between thinking and what is thought about. If the representation is the same as the reality represented, then we are satisfied. If they do not coincide, then we need to do more research about the reality and revision of the representation until they do. The fixation on mathematical sameness is, for Levinas, a function of the hegemony of the One conceived as the "I think" ([2], p. 220). Thought is essentially, he writes, "atheistic precisely as thought equaling the thought that fills and satis-fies it ..." ([2], p. 220; [3], p. 84). It plays the game of unveiling by which immanence always wins out over transcendence ([47], p. 56). ${ }^{30}$ The I seems devoted from the start to truth as representational adequation, grasping the given in its ideal identity ([48], p. 127). The logic of the atheistic I absorbs and assimilates what is different.

The words "god" and "transcendence" seem to gesture toward what is inherently unequal, toward that which is beyond the immanent sphere of intentionality. Thought is, for the atheistic I, a relation to what is equal to it. In such instrumentalized or calculative reason, the word "god" is taken as a label for an entity. For Levinas, taking the word "god" as a label indicates a mind incapable of understanding the meaning of the word "god" ([4], p. 75). Labels cut off this I and its thinking from "the beyond." However, we need to be careful here because the "beyond" just is the ethical sphere for Levinas. As Kant explains, there is no transcendence to a realm beyond objective appearances, to things in themselves independent of how they appear to us [30]. ${ }^{31}$ All application of categories beyond the field of sensibility generates illusions. The atheistic I is dissatisfied with mere appearances, and demands access to things in themselves. That is, we interpret phenomena as "mere" appearances instead of working on and with them as the reality they are. In this way, we expect transcendence to be wholly outside the world of ordinary finite experience. However, "inside" and "outside" are spatial forms of sensibility. ${ }^{32}$ To believe we can get to things themselves outside space and time is, as Gadamer underscores, to think as if one were like a god or like Lucifer ([26], p. 445). ${ }^{33}$

29 But, implicitly, the I has authority over the god in being able to name it.

30 As Levinas elaborates, any transcendence is converted into the immanence of intentionality with its noetic-noematic parallelism ([4], p. 70).

31 There are only transcendental conditions of possibility, what is necessary for what is knowable.

32 See Tillich's discussion of the concept of "first cause" as necessarily symbolic ([49], p. 209).

33 While we may have the idea of a god, there is no sensible appearance that would constitute the necessary elements for concrete existence. 
In light of this, Levinas asks, is it possible for thought to think better than it thinks ([2], p. 221)? ${ }^{34}$ Can the I do better than it thinks? How can we make sure we predicate "god" of fitting subjects? The question is not whether or not a god exists. It is, rather, who or what will be my god (see [51], p. 27)? To expect the word "god" to reference a specific entity is precisely the atheism of the atheistic I. The word "god" is a predicament in which to situate a subject, and not itself a subject term. The irony here is that even theists are atheistic in this sense. Proofs for or against the existence of a god are a subterfuge for the atheistic I, deflecting attention away from its insidiousness toward metaphysically transcendent alienness. Instead, let us re-orient ourselves to what Levinas calls "the fall of 'god' into meaning" ([52], p. 173). This is, Levinas emphasizes, the path of return from "heaven" to earth ([2], p. 221). ${ }^{35}$

I seek to articulate, as Simmons encourages, a robust epistemic humility regarding "god" and "transcendence"-not in terms of a god's metaphysical withdrawal, but in terms of critique of the atrophied atheistic I (see [43], p. 42). My three challenges to the atheistic I for its drift toward nihilistic reification, its masculine hegemony, and the intrinsic atheism of its instrumentalized reason humble the atheistic I's pretense to know reality. Since I have made all three challenges converge on language, particularly on the predicative link of discourse, I now turn to a semantics of metaphor to develop a path by which to bring the atheistic I down to earth.

\section{A Semantics of Transcendence}

Since transcendence is not about getting to another metaphysical place than the one we are already in, then can we make sense of "transcendence" in a different way? For Levinas, metaphor is itself the "movement beyond" ([4], p. 71). I take this as my lead for this section. How is metaphor the movement beyond or transcendence? In this section, I first examine a semantics of metaphor. Then I turn to the function of religious language in light of that. Third, I draw out implications this has for existential transcendence by emphasizing the ubiquity of metaphors in ordinary discourse.

If we approach metaphor as "mere" metaphor, then we will miss what is at stake. Such an approach to metaphor centers on names, privileging nouns over verbs or identification over predication (see [35]). This approach defines metaphor as the substitution of a nonconventional name in place of a conventional one. For example, "Hubert is a lion." This tempts us to believe there is some subject matter (Hubert, himself) that can be said without superfluous metaphorical decoration (in that he is obviously not a lion). Diminishing metaphor to word substitution serves the atheistic I by preserving its myopic focus on discourse as names and its inversion of subject and predicate. Normatively policed Christian theism benefits from this. We cannot—so they say-positively describe "God," and so our discourse about this god is merely anagogical or apophatic (see [54], p. 71; [55], p. 77; [56]).

In light of my challenges to the atheistic I, let us think metaphor otherwise. Ricoeur is helpful for formulating an alternative, defining metaphor as "impertinent predication" [35]. Rather than word substitution, metaphor is sentential where a subject is characterized, embellished, or enhanced by a predicate. A predication is "impertinent" when what appears as a first-order absurdity or contradiction sublates into a second-order reconciliation in understanding meaning ([57], pp. 50-55). We neither merely find meanings nor merely make them, because the difference between invention and discovery dissolves in metaphor. Rather, successful predication is where we "elevate" life to the logos, where a moment is illuminated by the light of discourse ([57], p. 19). ${ }^{36}$ However, this is the heart of predication as such. Via predication, a specified subject is reconciled with a more or less determinate field of

\footnotetext{
34 The existence or non-existence of a god does not really matter to people. This is not a sociological observation, though, such as noting the decline of interest in religion and the rise of the "nones" or noting the ubiquity of phoniness and anti-intellectualism of fervent religious practice. Rather, these are symptoms of the dis-ease of thought, the atheism of the modern subject. See ([50], p. 19; [12], p. 53).

35 Just as "god" does not denote a transcendent entity, "heaven" in not a transcendent place beyond this world. This applies just as much to how we conceive of "nirvana" as somehow an escape from samsara (see [53]).

36 See also Gadamer's discussion of the speculative character of predication ([26], p. 463).
} 
intelligibility in understanding-intelligibility constituted by forms of life, communities of practice, narrative traditions, and so forth. By virtue of predication, human beings live in a world and not merely survive in an environment. Through language, we transform our environments into meaningful worlds ([58], pp. 108-9).

The atheistic I's solipsism would have us believe that there is no communication with others. However, predication is a clue to our essential belonging with others. ${ }^{37}$ Fields of intelligibility are neither mine nor yours, but emerge through cultural accumulations or traditions (see [26,59]). This is why Levinas says transcendence is the opening of the finitude of being to "sociality" ([2], p. 222). ${ }^{38}$ When the hegemony of the atheistic I decreases, when we stop demanding all words be names, we can finally start speaking with each other and work together in the project of raising experiences to shared understandings. As Zhuangzi asks, "Where can I find [one] who has forgotten words, so I can have a few words with [them]?" ([61], p. 114). We carry (-phor) over (meta-) or translate mute events we experience into the verbally constituted intelligibility of understanding through dialog. In this light, as Levinas says, "metaphor is language" ([4], p. 71). The movement beyond is not from one metaphysical place to a wholly other one, but from isolated experiences to shared understandings. Predication is what someone has to say to another about a subject matter, putting it in its fitting intelligible predicament with and for others.

I emphasize the plurality of understandings because the atheistic I forgets the diversity of perspectives in its metaphysics, those points of view dependent on cultural accumulation and differentiation. ${ }^{39}$ There are multiple empirical languages and language-games, and every language-game reflects a distinctive shared form of life (see [60]). Each Lebensform opens its own field of intelligibility. However, the atheistic I imposes its "intelligibility" on this diversity, claiming to be the one exclusively true perspective. ${ }^{40}$ Indeed, in its insidious and unconscious conceit of exclusive accuracy, it loses the very factor definitive for what it is to have a perspective. As both Zhuangzi and Irigaray promote in distinct ways, perspectives are defined by (and thereby humbled by) their differences with other perspectives-that is, alternative perspectives put any particular perspective into perspective as what it is, one perspective among others. To recognize one's perspective as a (not "the") perspective is to recognize that there are some other perspectives meriting respect. For illustration's sake, perhaps our perspectives on era dating can clarify this. Many take for granted that it is $2016 \mathrm{CE}$, despite knowing that it is merely an attempt at secularizing the Christian era dating system. Our exclusivity is unconscious, complicit with institutional norms that undermine alternative practices, such as sending mail on Sunday. In light of this, there is a growing movement among Muslims advocating for Mecca Time, objecting to Greenwich Mean Time as intrinsically colonialist and Christian. Recognizing alternative timeframes can help expose our ordinary unconscious complicity in not seeing our own perspective as a perspective. One might be tempted here to turn to the carbon dating system of physics for the "true" date. ${ }^{41}$ Its accuracy is not at issue. It is simply that one cannot (yet) write a carbon date on an application for a job or birth certificate. How we organize time is developed through cultural accumulation, and cultures articulate time differently (see [62], p. 95). These perspectives on time are different languages.

Languages or fields of intelligibility are not only cultivated in distinct conventions and forms of life, but are also rooted in our biology. Intelligibility involves and invokes carnal tangibility.

37 As Heidegger describes discourse as the concretion of mitdasein ([37], pp. 114-22, 155-61).

38 We can ask with Levinas, then, "Why is there saying [at all]?" ([4], p. 71). If the atheistic I has it right, then language would be superfluous. Cf. Wittgenstein on the impossibility of "private language-games" [60].

39 Zhuangzi illustrates this in the parable of the frog within the well incapable of comprehending the ocean ([61], pp. 74-75).

40 For clarification, what is written is not against "exclusivists" (as defined in contemporary philosophy of religion, usually juxtaposed with inclusivists and Hick's pluralism). It is solely against the atheistic I's imposition of a singular perspective on what constitutes intelligibility-Hick may be just as "exclusivist" in this sense. For shortcomings of all three philosophical responses to religious diversity, see [62].

41 Gadamer criticizes the appeal to the discourse of physics as getting at the world in itself ([26], pp. 448-49). 
Predicative transcendence in metaphor takes place in this time and space. Irigaray calls this the "sensible transcendental" (see [63]) character of language that reaches out and touches others. Lakoff and Johnson, in corroboration, elaborate on numerous ways our fundamental conceptual metaphors are rooted in our biology. Conscious awareness is characterized as "up," for example, by virtue of our walking erect, whereas unconsciousness is characterized as "down" by virtue of lying down to sleep ([64], p. 15). The word "concept" derives from grasping things together with our hands. This tangible intelligibility of metaphor may be leverage for what Hershock-working from a classical Chan perspective-calls "nonduality," the elimination of social conflict and hegemony but not difference ([65], p. 85). Differences are always already interconnected, incarnated, and interwoven in human beings' bodies preceding interpretive or ideological imposition ([66], p. 117). By virtue of biological and lived difference, we are enabled to reach one another in trying to accomplish shared projects.

Attention to predication in this way preserves carnal embodiment the atheistic I neutralizes. ${ }^{42}$ The differences sought by the atheistic I establish utter separations, whereas embodied differences facilitate integration and connection without assimilation. ${ }^{43}$ Exclusive monotheism of the atheistic I draws an absolute yet abstract distinction between the divine and the human. As Irigaray puts the alternative, divinity arises from attraction between us ([44], pp. 147-51). That is, attraction amidst carnal differences gives us something of which to predicate "Oh, god!"44 Emphasizing predication in this way helps bring the atheistic I down to earth. The abstraction performed by naming and identification is overcome by situating the sentential subject in intelligible yet tangible predicaments.

The atheistic I is insidious, though. Words such as "transcendence" and "god" and "metaphor" are not all that is at issue. All our terms are questionable. Is a term being used as the atheistic I would have it or otherwise than that? In the atheistic I's taking an object for the absolute, it forgets the metaphorical and predicative character of the bond between understanding and the object. Forgetting this makes the metaphor or symbol into an idol ([13], p. 197). Thus, treating transcendence metaphysically seems to actualize as idolatry, whereas schematizing it as regulative is instantiated in elevation of subjects into intelligible predicates (see [13], p. 197). Nevertheless, as Simmons emphasizes, we cannot ignore the ontological and metaphysical in that the experience of transcendence does not seem limited to the merely linguistic, social, or ethical spheres. Certainly, religious apprehension includes yet exceeds moral and linguistic dimensions of experience (see [43], p. 147). However, are we talking about "moral" and "religious" and "ontological" and "metaphysical" within the terms set by the atheistic I? This is just what the atheistic I expects, and is a symptom of the glacial drift in consciousness toward reification. Like our calendars, these terms are coordinates in varying fields of intelligibility by which our experience is elevated to shared discourse and understanding. Understanding is as real as any other reality.

Like cardinal directions and calendars, religions are not mere descriptions of reality, as if they are just big names either identifying or misidentifying reality. Thinking that one religion is wholly true at the ultimate exclusion of other religions is a function of the atheistic I. Rather, religious discourses consist of metaphors—or symbols and myths—by which communities elevate their experiences into shared understanding with one another ([12], pp. 47-62). ${ }^{45}$ The word "god" is one such symbol.

42 Longing for something beyond touch misses transcendence within the finite. Rather, through fitting predication, we are brought back to touch as it underlies all other senses, touch by which everything else is given to us (see $[13,18]$ ). Because words are as material as they are meaningful, we touch each other with fitting words when we reach each other (see [46]).

43 Irigaray illustrates this by appeal to the placenta (see [45]).

44 As noted above with Ricoeur on metaphor, language gets started with predication (see [57]). Like other sentences with implied subjects (such as "Go!"), this ejaculation too appears best analyzed in light of the foregoing as a predicate with an implied subject (such as, "This ... is so awesome ... " or "This ... is my god.").

45 Theology organizes those symbols and myths in accord with philosophical concepts and existential questions emerging from occasion to occasion. See Tillich's "method of correlation" ([49], pp. 59-65). Religions-in as much as they exist beyond imperialist categorization (see [36])—are more complex phenomena than mere words, including festivals, calendars, rituals, moods, and more. 
In a culture where the word "god" structures and is structured by a broader field of intelligibility, a participant in that culture may look for something of which or someone of whom to predicate "god" (see [32,51]). This is what one does in asking, "Who will be my god?" (Other religious communities are structured by other symbols, such as "buddha" or "dao.") When a community is touched by the fitting use of the predicate for that thing or person, it is the fall of "god" into meaning that Levinas stresses. It is the living operation of the predicate in shared understanding. The early followers of Jesus, looking for one of whom to predicate "messiah" or even "god," found in Jesus an answer to their question of "Who or what will be my god?" As Scharlemann explains, "One can understand why Jesus' career ran the course it did if the essence of God, what it means for God to be God, is to be other than God" ([32], p. 84). Words like "god" take on meaning only in between us, conferring meaning on existence through our predicating it of experiences, events, things, persons, sex, and more. Yet, the word "god" also designates the reach of existential transcendence in predication to include but exceed itself in a surplus of further predications, and understanding builds on itself through the hermeneutic circle ([67], p. 168). The self-surpassing element in the word "god" opens our minds to what is truly mysterious-the miracle of shared understanding in conjunction with the mystery of subjects copulating with predicates (see [57], p. 16). Such transcendence cannot be reified into a mere nameable supreme being ([67], p. 168). ${ }^{46}$

As metaphorical predicates, representations of the divine are brought down to earth. As Irigaray emphasizes, divine representations are mere idols if they do not support natural growth and becoming ([46], pp. 144-48). Through fitting predications, we transubstantiate our matter into subtler divine matter ([46], p. 173). However, this is no escape from some prison of the material or natural world, as the atheistic I might have it. In our transubstantiation, we become even more what we truly are in the joy of recognition. This is not a progression toward some transcendent state of perfection, but an ever-renewing blossoming in further understanding. Both material and spiritual supports should serve such blossoming. Dominant abstract concepts of "nature" and "culture" occlude this, though. Nature is usually treated as that which grows by itself, while culture is treated as where we make things ([46], pp. 112-25). Blossoming requires both making and letting be, involving both invention and discovery. What blossoms often bears fruit. The fruit of understanding is "meaning." The blossoming of experience into understanding occurs through metaphorical predications. In all this blossoming, we cultivate a surplus of meanings.

Once we reserve our use of the word "god" to predication rather than denomination, we open ourselves to the superabundance of meanings available in varying uses of the word. We are freed from having to restrict our use to this or that context, as if some uses are inherently blasphemous while others are inherently sacred. We can recognize that a god is only personal if the subject of the sentence refers to a person or character with a personality. However, the word need not be restricted to predications of persons. Indeed, as Tillich underscores, anything that one treats with ultimate concern - that is, anything one lives one's life around-is one's "god" ([12], p. 2). Things as diverse as money, success, nations, and more can be and have been gods for people. The blasphemy comes not from use of the word "god," but from how the subject of the sentence-say, money-is treated. ${ }^{47}$ When one lives for money and sees another person treat money with disrespect, that is what is blasphemous. ${ }^{48}$ These considerations help us develop the intelligibility of the word "god," where we cultivate a spiritual and intellectual elevation in literacy that is neither a subordination of oneself in debt and guilt to a

46 Idolatry is, then, the totalizing identification of transcendence solely with a specific god adopted in history.

47 This is particularly relevant for the contemporary phenomenon of many Jewish writers refusing to write out the word "G-d." See this addressed above.

48 We might go so far as to wonder-especially in light of Irigaray's advocacy that the divine emerges from attraction between the sexes-whether saying "Oh, my god!" at the moment of orgasm is not a more semantically fitting predication than its use in arguments for or against "the existence of god." 
supreme god nor an absorbing communion with a god in an emotional orgy. As Feuerbach writes, "The Word of God is really the divinity of the human word" ([14], p. 79).

My proposal is that a semantics of transcendence provides sufficient groundwork for an alternative to the hegemony of the atheistic I and its forcing us to see transcendence in a peculiar way. However, is this semantics of transcendence patronizing or unethical to historical participants in religions, as Simmons raises the question $?^{49}$ In other words, it seems that many participants in religions-perhaps so-called "evangelicals" or "fundamentalists" or "literalists," but even more just the lay practitioner regularly involved in worship or meditation-take their religion as the most adequate description of reality, where their gods exist as metaphysically transcendent entities. The approach taken here to explain the discourse of religions seems to undermine them to the point of dismissing them in favor of what they may see as mere rhetoric. They might take my argument as merely about words, whereas they are truly concerned with "God Himself." 50 This is a particularly relevant concern for Religious Studies scholars navigating their relation(s) with their "objects" of study (see discussions surrounding, for example, [69]). How ought "outsiders" treat "insiders"?

While this is an ongoing and complex discussion in Religious Studies (and probably more relevant for philosophies of religions than many professional philosophers may think), I want to contribute to it in terms of how "insiders" see "outsiders." I want to sketch a consideration by way of an analogy with how we enjoy and explain "sunsets." I am confident many people have enjoyed a sunrise or a sunset. I am also confident that the majority of these people learned that the earth rotates around the sun. That is, they know that the sun does not technically set or rise, but instead realize they are under an illusion if they take "sunrise" or "sunset" as descriptions of what is happening outside of what appears to them from their perspective. Nevertheless, this bothers few. Most of us genuinely enjoy sunsets. There might even be some people who believe it actually rises or sets. However, we would not suggest a textbook is patronizing or unethical to them. If we were with them, and said something such as "What a beautiful earth-spin!" we all would likely laugh together rather than bristle up in adversarial argument. I go into detail not because there is an analog between enjoying a sunset and worshipping a god, but because there is an analog between the textbook and the scholar of religion. Just as the textbook as it is read in a science class is not subject to a moral criticism, neither ought the scholar of religion be subject to such a criticism when communicating with other scholars. It is not like we are at the sunset telling them how wrong they are!

Approaching transcendence semantically opens up what I call the poetic redemption of the real. Through predication, we lift subject matters into the light of discourse. This is liberating because discourse needs no purpose beyond itself. The atheistic I instrumentalizes discourse to some extrinsic purpose or interest. Discourse, however, has its ultimate end in itself. ${ }^{51}$ However, this does not reduce discourse to "jibber jabber" or "idle talk" ([61], p. 66). We escape "mere" words, Zhuangzi encourages, in order to take poetic delight in them ([73], p. 60). Like Socrates, we are freed to follow the logos,

49 Simmons asks this of Levinasian influenced philosophical theology and postmodern reconstructivism (see [43], p. 39; [68], p. 162).

50 I want to point out that my proposal is even more severe than saying they do not know what they mean when-say-they pray to their god. I am saying that most language users have forgotten basic grammar school distinctions between subjects and predicates, the necessary parts for formulating complete thoughts. That is, I am calling out everyone who has succumbed to the hegemony of the atheistic I as unable even to think otherwise than in the mode of instrumentalized reason. Therefore, it may seem that my argument is even more problematic than merely dismissing religious practitioners as interlocutors who may be saying something true.

51 As Searle explains in his theory of speech acts, there are five things people do with words. He writes, "There are ... five general categories of illocutionary acts. We tell people how things are (Assertives), we try to get people to do things (Directives), we commit ourselves to doing things (Commissives), we express our feelings and attitudes (Expressives), and we bring about changes in the world through our utterances (Declarations)" ([70], p. viii). While we might use discourse to accomplish any number of things, language-in my sense of the poetic redemption of the real-is its own end. I base this on Gadamer's point that language comes into its full "ideality" in literature (see [26]), and on Ricoeur's point about writing bringing language into the fullness of its being (see [71]). I also find Hegel's theory of art helpful here where he distinguishes limited purposes or uses of art from its ultimate purpose (see [72]). 
which is like the wind taking us whatever way it blows ([74], p. 73). Moreover, metaphors permeate our lives. They are so ordinary they form the tillable sediment of fertile intelligible potential and growth of ever more metaphors. Most events in our lives are things metaphors are made of! This phenomenon is the heart of discourse, as discourse is defined by predication, by having something to say about things. However, this is so ordinary that it often goes on without notice. Let us turn in conclusion to dwell on features of ordinariness that shed further light on bringing the atheistic I down to earth.

\section{Toward a Rehabilitation of the Ordinary as an Eschaton}

In conclusion, I explore aspects of the ordinary as that which orients transcendence as its fulfillment, as a possible eschaton. ${ }^{52}$ I first elaborate on ways in which various oppressions may distort ordinary life, particularly with their normalization. Second, I turn to try to isolate the generative and transformative essence of the ordinary. Third, I conclude reflecting on what seem to be forms of life consummated in the ordinary. Although transcendence is usually juxtaposed with immanence in most contemporary philosophy of religion, transcendence is defined by reference to ordinary circumstances. Relative to the god(s) of the atheistic I or traditional theism, the ordinary may seem empty or even futile. ${ }^{53}$ The atheistic I expects the extraordinary. The ordinary is, as Weiss and Heidegger differently elaborate, the multifaceted horizon contextualizing all concentration and interpretation, which is distorted by oppressive values. Making us self-conscious about the insidious constitutive character of the atheistic I provides leverage for resistance to multiple oppressions that people face, and helps exhaust the invisible effect of what Anderson calls "white solipsism" on theology and philosophy ([13], p. 206).

It is difficult to elaborate on the ordinary as if there were some universal or pure essence uncoverable if we work through all its distortions. I want neither to re-inscribe the polarity of the sacred and the profane as definitive for religious experience as with Eliade [76], nor to turn to the secular as the default interpretive frame for the modern world as with Taylor [77]. ${ }^{54}$ I also do not think it is synonymous with the "heavenly" natural flow of things in early philosophical Daoism. Nevertheless, there is always a dynamic horizon or background taken for granted from which anything extraordinary stands out. Perhaps it is illustratable by Shinto torii that stand amidst everyday life, integrated in a city street or standing alone in a natural clearing ([79], pp. 138-39). As one passes through such a gate- purporting to transport one from the profane world to a sacred realm—one ends up right back where one already was. Such a moment might be called "transcendent," not because one moves beyond this world to another metaphysical plane, but because one is opened to living here and now.

Yet, it is undeniable that for many people severe oppression is normalized, where everyday life is structured by sexism, racism, and classism [66]. In the midst of war, people directly face destruction and the threat of their own death on a daily basis. Even the horrors of suicide bombings are routinely

52 The world-famous chef, Bourdain, recently published on his transition from exploring exquisite cuisines to daily cooking for his child. This is illustrative of the quest for the ordinary I am after in this section. He writes, "What is it that normal people do? What makes a normal happy family? How do they behave? What do they eat at home? How do they live their lives? I had little clue how to answer these questions for most of my working life as I'd been living it on the margins. I did not know any normal people. From age 17 on, normal people had been my customers. They were abstractions, literally shadowy silhouettes in the dining room of wherever it was I was working at the time. I looked at them through the perspective of the lifelong professional cook and chef, which is to say as someone who did not have a family life, who knew and associated only with fellow restaurant professionals, who worked while normal people played and who played while normal people slept. To the extent that I knew or understood normal people's behaviors, it was to anticipate their immediate desires. Would they be ordering the chicken or the salmon? I usually saw them only at their worst-hungry, drunk, horny, ill-tempered, celebrating good fortune or taking out the bad on their servers. What they did at home, what it might be like to wake up late on a Sunday morning, make pancakes for a child, watch cartoons, throw a ball around a backyard, these were things I only knew from movies. The human heart was and remains a mystery to me, but I'm learning. I have to" ([75], pp. 1-2).

Indeed, some think there is nothing worse than being ordinary. Others, however, long to live a normal life.

54 Cf. [78]. 
wrestled with [80]. Only someone from a position of social privilege could say these are somehow distortions of normal life as if there were some ideal of universal normalcy in light of which all these should be judged. As Weiss writes,

One must always be cognizant of the fact that sedimentation of everyday experience into recognizable patterns can serve to codify oppression as readily as it can promote a reassuring sense of existential stability ... To avoid complacency, one must be attentive to continual possibilities for transformation offered by those aspects of the world that cannot be rendered intelligible within established horizons, and that therefore demand new ways of thinking, feeling, and being ([66], p. 5).

However, criticism of-say-heteronormativity and the accompanying bullying that tries to preserve normalized patriarchal values involves an ethical criticism, that there is a different way to be besides this one structured by oppression (see [81]). Where do these "possibilities for transformation" that "cannot be rendered intelligible within established horizons" come from?

Even our desires for how things may be can be a source of frustration and alienation from the ordinary. Our desires can prevent us from seeing what really goes on. Under the condition of the atheistic I's distorted sense of "self," we entrench our horizons for relevance, picking and choosing experiences and information according to whatever serves our self-interests ([65], p. 139). As Hershock illustrates, suffering is not as easily addressed as pain because responding to suffering involves knowing the expectations violated, the cultural and personal impasses reached, and which parts of the situation are even negotiable ([65], p. 15). Hershock elaborates on this by pointing to how many perceive the death of a child as more traumatic than the death of someone several decades older. There is not any difference in the process of dying. The difference is in our desires, and these desires are often determined by hegemonic interests of the atheistic I. However, this is not a conscious act or choice.

Heidegger approaches the inculcation toward self-interest as the everydayness of dasein where one is colonized by the they ([37], pp. 112-74). The they, for Heidegger, names who one is on the whole and for the most part. One does not live in reflective contemplation, but is immersed in the task of getting on with one's life with others. We all fall back on the they in rationalizing what we do each day. The they is always peculiar to an age or culture. ${ }^{55}$ Our everydayness is structured by discrete conventions of activity and discourse. The they always seeks what is new, and take distanced aesthetic pleasure in things through idle talk, curiosity, and ambiguity. In our era of social media, these aspects of the they are exacerbated and amplified (see [82]). The speed at which memes pass through digital culture is overwhelming, where everything is always new (yet always the same!). Absorbed into this world, one lives as everyone does: as no one in particular. The they pre-interpret the world for one, determining the significance of things for one ahead of time. Thus, the drift toward the atheistic I is not merely a reaction to being wounded by the infinite, as Levinas has it, but is also a function of our absorption in the everydayness of the they.

Following Irigaray and Huang, one source of oppression and leveling in this everydayness is not respecting differences (see $[45,83]$ ). The atheistic I treats all things on the logic of sameness. Thus, recognition and respect for difference might provide an alternative way forward. As Huang explains, this need not involve subordination of one to the other. One can respect others for who they are or even for who they think they are. Zhuangzi illustrates this in a parable questioning the tendency to treat all other things according to one's preferences:

The emperor of the southern sea was called Swoosh. The emperor of the northern sea was called Oblivion. The emperor of the middle was called Chaos. Swoosh and Oblivion would sometimes meet in the territory of Chaos, who always attended to them quite well. They decided to repay Chaos for his virtue. "All men have seven holes in them, by means

55 Why do Americans drive on the right hand side of the road? Because that is what one does here. 
of which they see, hear, eat, and breathe," they said. "But this one alone has none. Let's drill him some." So each day they drilled another hole. After seven days, Chaos was dead ([61], p. 54)..$^{56}$

Even with the best of intentions, without respecting differences one might-without even realizing it-negate the other. Differences are ordinary. Perhaps, as Huang emphasizes, only something like water can respect the plurality of things. Water accepts the mold of things without changing what either is (see [83], p. 81). However, in addition to respect for differences, I think we also need to look further into the condition in which there is a production of a surplus of differences. What I am calling the ordinary seems to be, in large part, this locus of generativity of differences.

Despite the codification of oppression and absorption in the they, possibilities for transformation or authenticity still seem available-such as through owning one's death in angst or reconnecting with our bodies or through Zhuangzi's approach to the dao. Bringing the atheistic I down to earth involves, foremost, bringing it back to the body. The body is a key limitation on the breadth of one's perspective. Feminism's "corporeal politics" is especially clear on this in critiquing the question of transcendence as if it led above and beyond the ordinary material world (see [84]). Getting back to one's body not only provides leverage for critique of masculine subjectivity, but is crucial for health (see [45]). The body is taught to detach itself from sensibility in favor of an abstract culture. We grow up separating "culture" and "nature," separating "corporeal life" and "spiritual life," forgetting that "the soul corresponds to the life of the body cultivated to the point of acquiring autonomy and spiritual becoming ..." ([16], p. 75). ${ }^{57}$ Every point of view or perspective is cultivated in relation to a specific body. Moreover, the body is the guarantee that individuals will be different, that no two individuals will occupy the same space and have the same horizons ([66], p. 117). Transformative and generative possibilities emerge, as Weiss elaborates, from the body's dynamic interactions with different others in varying contexts ([66], p. 138).

A virtue of both contemporary feminist social epistemology and classical Zhuangzian contextualism ${ }^{58}$ is the attentiveness to seeing reality from alternate perspectives. But what is this phenomena lending itself to a multiplicity of perspectives? I propose exploring it as something approximating Zhuangzi's "dao," a purposeless furnace of transformations (see [61], p. 46). Despite the variety of perspectives, Zhuangzi suggests there is some underlying unity, a oneness of what he calls "the Heavenly" ([61], p. 48). In Zhuangzi, the dao functions as a regulative ideal exposing not only that there are multiple perspectives available at any moment, but even more that every perspective is limited ([61], pp. 18, 74-75).$^{59} \mathrm{It}$ is the purposeless background to every purpose or "way" in the foreground ([87], p. 43). In light of Zhuangzi's "dao," I want to describe the ordinary as the undifferentiated background or horizon from which particular things or purposes stand out. With Weiss, this indeterminacy should not be understood as on the fringes of perception, but permeating all aspects of it from the fringes to the center ([66], p. 37). How can disruption of normalcy be a hope for those subject to systemic oppression or constancy of violence? It opens possibilities for disrupting oppressive normalcy.

The atheistic I quests after what is "extra-ordinary" or "outstanding," or even its own "originality." It obscures the fact that such objects are foregrounded from the background that transcends all of them. By so obscuring this fact, the I treats outstanding things as transcendent entities to which it clings for security. However, in attending to the undifferentiated background from which "special" things are differentiated, I hope we can start to overcome the hegemony of the atheistic I. ${ }^{60}$ Rather than

56 For Zhuangzi, all things have their own intrinsic principles that need to be respected.

57 See also [85], where Wenzel emphasizes Zhuangzi's similar focus on the body as the locus of autonomy. Perhaps surprisingly, this is also Aquinas's Aristotelian approach to the soul-it is "outside," not "inside," the body (see [55], pp. 119-21).

58 I call it "contextualism" in order to bypass worry about Zhuangzi's so-called "relativism."

59 Cf. [86].

60 And this seems remarkably consistent with the ancient Greek approach to truth as "alethia," where something shows itself and is seen for what it is in its relation to and differentiation from the background. It is not that we then can represent the 
seeing these special things as transcendent, it is the background that transcends the limited narrowness of particular perspectives focused on this or that as extraordinary ([61], p. 12). The contrived and utilitarian thinking of the atheistic I oscillates between "this" or "that," but such thinking stands in opposition to the fluidity of the ordinary. Fluid thinking with the flow of the ordinary is not trapped by the rigidity of representations imposed by the atheistic I (see [73], p. 56). When one lets go of forcing things to fit pre-established representations, we can forget the need for things to fit only in a certain way.

If it is fitting to approach the ordinary this way, then we need not treat it as something from which one needs to escape. Instead, it may be precisely what fulfills one. Being opened toward the ordinary makes possible existential transformation, where one's identity is fluid and responsive to changing circumstances. In this way, the fecundity and natural blossoming of the ordinary is like the self-presenting and self-justifying character of play. In his ontology of play, Gadamer underscores that play is not merely in the power of the subject playing, but really is an unfurling of the subject matter through the players. As he states, "All playing is a being played" ([26], p. 106). ${ }^{61}$ Play absorbs the players-including the audience-in the self-presentation of the game or play itself. It involves a dynamic and fluid to-and-fro movement. What makes such moments worthy of being predicated as "transcendent" is when the play brings one into true being, in the joy of recognition and knowledge of the really real (see [88]).

In this eschatology of the ordinary, such consummation in the ordinary seems to be the ultimate spiritual state underscored in Zhuangzi's daosim. It is not where one is transported to a transcendent place above or beyond this world, but a centered and adaptive responsiveness in this world ([89], p. 160). This is not a mere "flow state," but a state of self-conscious concentration. Zhuangzi's famous illustration of such a concentrated state is the story of Cook Ding, who never has to sharpen his knives because he is so attuned to the dao (see [85]). Ding says,

What I love is the Course ... I depend on [Spontaneous] perforations and strike larger gaps, following along with the broader hollows. I go by how they already are, playing them as they lay ... Whenever I come to a clustered tangle, realizing that it is difficult to do anything about it, I instead restrain myself as if terrified, [keeping my eyes on what I'm doing]. My activity slows, and the blade moves ever so slightly ([61], pp. 22-23).

Ding still needs to stop and think in particularly difficult circumstances. Reflection and thinking are not in strict opposition to the "flow state" of concentrated effort. Nevertheless, resting transparently on the ordinary liberates one from this or that contrivance and obligation to do or to force things. The thinking is fluent, in accord with the fluidity of the dao. Similarly, Kierkegaard-writing as Silentio-describes the paradoxical character of knights of faith ([90], pp. 49-50). They seem indistinguishable from other ordinary people. Whereas knights of infinite resignation can be detected through their awkwardness in the everyday, knights of faith relish this life. They are, he claims, just as graceful in their landing as in their leaping ([90], p. 41). Living in the ordinary involves not longing for another transcendent world but being gracefully concentrated in this one.

The grace to live in the ordinary affirms this life itself as sacred. It is not that institutionally sanctioned ritual acts in religious communities confer sacredness on ordinary activities such as breaking bread or drinking wine. Instead, these religious rituals are readable as affirming the intrinsic sacredness of the ordinary practices themselves. As Feuerbach says,

If thou art inclined to smile that I call eating and drinking religious acts, because they are common everyday acts, and are therefore performed by multitudes without thought,

fact with (in)accuracy. An alethic truth is articulated through a fitting predication, whereby the subject matter is raised to the light of discourse. See [32].

61 Where participants increase significance through spending themselves on the tasks set to them by the play. But this is not an event where one is transported to another world, a metaphysically transcendent world. 
without emotions; reflect, that the Lord's Supper is to multitudes a thoughtless, emotionless act, because it takes place often; and, for the sake of comprehending the religious significance of bread and wine, place thyself in a position where the daily act is unnaturally, violently interrupted...It needs only that the ordinary course of things be interrupted in order to vindicate to common things an uncommon significance, to life, as such, a religious import. Therefore let bread be sacred for us, let wine be sacred, and also let water be sacred! ([14], pp. 277-78)

Religions serve to remind one that every bath is a baptism, that every meal is communion. ${ }^{62}$ Religions are poetic redemptions of the real, returning sacred significance to the ordinary as this is distorted through normalization of hierarchical differences and accompanying oppression. I think it is worth considering that it is the interruption or distortion of the ordinary course of things that one could want to overcome; not transcendence from the ordinary to some other world. The inversions performed by the interests of the atheistic I lead to expecting transport to this other world from religious rites. The point is not to placate oneself in one's interpretation of the world, but is to change it.

This is not merely a problem in Western religions. Meditation in Buddhism is often approached instrumentally, as a means by which one can deliberately bring about an inner experience of enlightenment or realization of nirvana. This construal occurs as much today as always. Yet, the duality of such instrumentalization incapacitates one to recognize the interconnectedness of all things, the Buddha's fundamental insight of pratitya-samutpada (see [91,92]). Many Chan masters were already teaching against such conceptualization in the early phases of Chan (see [93]). Mazu, for example, teaches "Ordinary mind is the Way!" (see [94,95]). As the twelfth century Soto founder, Dogen, teaches: "Your very mind is Buddha" ([96], p. 24). Faure explains this:

The founder of the Soto sect, Dogen, transformed the practice of zazen (which he referred to as shikan taza or "sitting only") into a sort of absolute... It is no longer about introspection, but is instead a kind of ritual imitation of the emblematic posture of the buddhas. Followers sit and meditate not to achieve Awakening, but because this is exactly what buddhas do ([97], p. 78).

Just as eating bread is itself sacred, meditation is itself enlightenment and not a means to enlightenment. This is not to say that there are not peculiar subjective experiences that characteristically accompany enlightenment, but that seeking subjective experience or subjective transformation misses the intrinsically public and performative character of awaking. ${ }^{63}$

In all these ways, getting back to the ordinary helps bring the atheistic I down to earth. Affirming the ordinary in these ways seem to encourage us to transcend and escape the inverted world constructed by and imposed by the atheistic I. Through the ordinary, we might transcend the theisms of the atheistic I, perhaps meeting what Tillich calls "the God beyond God" ([100], pp. 176-90). It lets us see the magic in the ordinary (see [101]). The most profound growth occurs in our quotidian day in and day out conventions, where discursive culture continually lifts our spirits to ever more refined blossoming. ${ }^{64}$ As Plato closes his reflection on the ideal integration of a soul and a city, he affirms Odysseus's selection of a simple life despite drawing the short straw ([74], pp. 300-1). Philosophy does not help him find transcendence, in that it does not liberate him to a transcendent realm of so-called "Platonic Forms" (see [9]), but helps him make a respectable decision by which he can realize the good life in a simple life here and now.

62 I think this applies just as much to art. Religious art reminds us of the holiness in every artwork worthy of the name.

63 See $[98,99]$.

64 I want to thank Chris Lammer-Heindel for pointing me to Caputo's recent work (see [40]) during the revision process. It appears at first glance that my project here parallels and diverges from Caputo in interesting ways, one key difference being his focus on the name "God" exclusively in Christian theology, which I hope to develop in further research. 
Acknowledgments: I want to thank Brian C. Kanouse and Christoffer Lammer-Heindel for invaluable conversations inspiring this project. I am also grateful to two reviewers for their critical and constructive comments on previous drafts.

Conflicts of Interest: The author declares there are no conflicts of interest.

\section{References}

1. Luce Irigaray. "Love of the Other." In Ethics of Sexual Difference. Translated by Carolyn Burke and Gillian C. Gill. Ithaca: Cornell University Press, 1993, pp. 133-50.

2. Emmanuel Levinas. "The Idea of the Infinite in Us." In Entre Nous: Thinking-of-the-Other. Translated by Michael B. Smith and Barbara Harshav. New York: Columbia University Press, 1998, pp. $219-22$.

3. Paul Ricoeur. Husserl: An Analysis of His Phenomenology. Translated by Edward G. Ballard and Lester E. Embree. Evanston: Northwestern University Press, 2007.

4. Emmanuel Levinas. "Hermeneutics and the Beyond." In Entre Nous: Thinking-of-the-Other. Translated by Michael B. Smith and Barbara Harshav. New York: Columbia University Press, 1998, pp. 65-76.

5. Anne Hendrik Verhoef. "Transimmancence and the Im/possible Relationship between Eschatology and Transcendence." Religions 7 (2016): article 135. [CrossRef]

6. Mark C. Taylor. After God. Chicago: The University of Chicago Press, 2007.

7. Joerg Rieger, and Edward Waggoner, eds. Religious Experience and New Materialism: Movement Matters. London: Pelgrave MacMillan, 2016.

8. Diana Coole, and Samantha Frost, eds. New Materialisms: Ontology, Agency, and Politics. Durham: Duke University Press, 2010.

9. Hans-Georg Gadamer. The Idea of the Good in Platonic-Aristotelian Philosophy. Translated by P. Christopher Smith. New Haven: Yale University Press, 1986.

10. Judith A. Berling. "Bringing the Buddha down to Earth: Notes on the Emergence of 'Yu-Lu' as a Buddhist Genre." History of Religions 27 (1987): 56-88. [CrossRef]

11. Kevin Schilbrack. Philosophy and the Study of Religions: A Manifesto. West Sussex: Wiley-Blackwell, 2014.

12. Paul Tillich. Dynamics of Faith. New York: HaperCollins, 2001.

13. Pamela Sue Anderson. "Gender and the Infinite: On the Aspiration to Be All There Is." International Journal for Philosophy of Religion 50 (2001): 191-212. [CrossRef]

14. Ludwig Feuerbach. The Essence of Christianity. Translated by George Eliot. Amherst: Prometheus Books, 1989.

15. Paul Tillich. Biblical Religion and the Search for Ultimate Reality. Chicago: The University of Chicago Press, 1955.

16. Luce Irigaray. Between East and West: From Singularity to Community. Translated by Stephen Pluhacek. New York: Columbia University Press, 2002.

17. Eugene Thomas Long. "Suffering and Transcendence." International Journal for Philosophy of Religion 60 (2006): 139-48. [CrossRef]

18. Luce Irigaray. "Divine Women." In Sexes and Genealogies. Translated by Gillian C. Gill. New York: Columbia University Press, 1993.

19. Jerome Gellman. “In Defence of a Contented Religious Exclusivism.” Religious Studies 36 (2000): 401-17. [CrossRef]

20. Vine Deloria Jr. God is Red: A Native View of Religion, 30th Anniversary ed. Golden: Fulcrum Publishing, 2003.

21. Theodor Adorno. "The Perennial Fashion-Jazz." In Prisms. Translated by Samuel and Shierry Weber. Cambridge: MIT Press, 1981.

22. Richard Rubenstein. After Auschwitz: History, Theology, and Contemporary Judaism, 2nd ed. Baltimore: The Johns Hopkins University Press, 1992.

23. Hans Jonas. “The Concept of God after Auschwitz: A Jewish Voice.” The Journal of Religion 67 (1987): 1-13. [CrossRef]

24. Paul Ricoeur. "Life: A Story in Search of a Narrator." In Facts and Values: Philosophical Reflections from Western and Non-Western Perspectives. Edited by Marinus Doeser and John Kray. Translated by John Kray and A. J. Scholten. Dordrecht: Martinus Nijhoff Publishers, 1986.

25. Alasdair MacIntyre. After Virtue. Notre Dame: University of Notre Dame Press, 1981.

26. Hans-Georg Gadamer. Truth and Method, 2nd Revised ed. Translated by Joel Weinshimer and Donald G. Marshall. New York: Continuum, 2004. 
27. John R. McRae. Seeing through Zen: Encounter, Transformation, and Genealogy in Chinese Chan Buddhism. Berkeley: University of California Press, 2003.

28. David E. Klemm. "'Darkness inside the Human Soul': Uncertainty in Theological Humanism and Michael Frayn's Play Copenhagen." Literature and Theology 18 (2004): 292-307. [CrossRef]

29. Edmund Husserl. "Phenomenology." Translated by Richard E. Palmer. Journal of the British Society for Phenomenology 2 (1971): 77-90.

30. Immanuel Kant. Critique of Pure Reason. Translated by Marcus Weigelt. London: Penguin Classics, 2007.

31. Jean-Paul Sartre. The Transcendence of the Ego: An Existentialist Theory of Consciousness. Translated by Forrest Williams and Robert Kirkpatrick. New York: Hill and Wang, 1960.

32. Robert P. Scharlemann. The Being of God: Theology and the Experience of Truth. New York: Seabury Press, 1981.

33. Robin O. Andreasen. "Race: Biological Reality or Social Construct? " Philosophy of Science 67 (2000): S653-S66. [CrossRef]

34. Zygmunt Bauman. "Survival as a Social Construct." Theory, Culture \& Society 9 (1992): 1-36. [CrossRef]

35. Paul Ricoeur. The Rule of Metaphor. Translated by Robert Czerny. London: Routledge Classics, 2003.

36. Tomoko Masuzawa. The Invention of World Religions: Or, How European Universalism Was Preserved in the Language of Pluralism. Chicago: The University of Chicago Press, 2005.

37. Martin Heidegger. Being and Time. Edited by Dennis J. Schmidt. Translated by Joan Stambaugh. Albany: SUNY Press, 2010.

38. Thich Nhat Hanh. Going Home: Jesus and Buddha as Brothers. New York: Riverhead Books, 1999.

39. Paul Tillich. Systematic Theology, Volume II. Chicago: The University of Chicago Press, 1957.

40. John D. Caputo. The Weakness of God: A Theology of the Event. Bloomington: Indiana University Press, 2006.

41. Sumbul Ali-Karamali. The Muslim Next Door: The Qur'an, the Media, and that Veil Thing. Ashland: White Cloud, 2008.

42. J. Aaron Simmons, and John Sanders. "A Goldilocks God: Open Theism as a Feuerbachian Alternative." Element 6 (2015): 34-53.

43. J. Aaron Simmons. "In Whom, Then, Do We Put Our Trust? " Journal for Cultural and Religious Theory 11 (2011): 37-45.

44. Friedrich Nietzsche. On the Genealogy of Morals: A Polemic. Translated by Douglas Smith. Oxford: Oxford University Press, 2008.

45. Luce Irigaray. Je, Tu, Nous: Toward a Culture of Difference. Translated by Alison Martin. London: Routledge Classics, 2007.

46. Luce Irigaray. The Way of Love. Translated by Heidi Bostic and Stephen Pluhacek. London: Bloomsbury, 2002.

47. Emmanuel Levinas. "A Man-God? " In Entre Nous: Thinking-of-the-Other. Translated by Michael B. Smith and Barbara Harshav. New York: Columbia University Press, 1998, pp. 53-61.

48. Emmanuel Levinas. "Nonintentional Consciousness." In Entre Nous: Thinking-of-the-Other. Translated by Michael B. Smith and Barbara Harshav. New York: Columbia University Press, 1998, pp. 123-32.

49. Paul Tillich. Systematic Theology, Volume I. Chicago: The University of Chicago Press, 1951.

50. Emmanuel Levinas. "The I and the Totality." In Entre Nous: Thinking-of-the-Other. Translated by Michael B. Smith and Barbara Harshav. New York: Columbia University Press, 1998, pp. 13-38.

51. John D. Caputo. On Religion. London: Routledge, 2007.

52. Emmanuel Levinas. "Diachrony and Representation." In Entre Nous: Thinking-of-the-Other. Translated by Michael B. Smith and Barbara Harshav. New York: Columbia University Press, 1998, pp. 159-78.

53. Thich Nhat Hanh. Living Buddha, Living Christ. New York: Riverhead Books, 2007.

54. Moses Maimonides. The Guide of the Perplexed, Abridged ed. Translated by Daniel Frank, Julius Guttman and Chaim Rabin. Indianapolis: Hackett Publishing, 1995.

55. Thomas Aquinas. A Shorter Summa: The Essential Philosophical Passages. Edited by Peter Kreeft. San Francisco: Ignatius Press, 1993.

56. Edmond La Beaume Cherbonnier. "The Logic of Biblical Anthropomorphism." The Harvard Theological Review 55 (1962): 187-206. [CrossRef]

57. Paul Ricoeur. Interpretation Theory: Discourse and the Surplus of Meaning. Fort Worth: Texas Christian University Press, 1976. 
58. Paul Ricoeur. "What is a text? Explanation and Understanding." In From Text to Action: Essays in Hermeneutics, Volume II. Translated by Kathleen Blamey and John B. Thompson. Evanston: Northwestern University Press, 1991.

59. Alasdair MacIntyre. Three Rival Versions of Moral Enquiry: Encyclopedia, Genealogy, and Tradition. Notre Dame: University of Notre Dame Press, 1990.

60. Ludwigr Wittgenstein. Philosophical Investigations, 4th Revised ed. Translated by Gertrude Elizabeth Margaret Anscombe, Peter Hacker and Joachim Schulte. Oxford: Blackwell Publishing, 2009.

61. Zhuangzi. Zhuangzi: The Essential Writings with Selections from Traditional Commentaries. Translated by Brook Ziporyn. Indianapolis: Hackett Publishing, 2009.

62. Nathan Eric Dickman. "Ethical Understanding: The Priority of Questioning in Interreligious Dialogue." Listening: Journal of Communication Ethics, Religion, and Culture 50 (2015): 92-105.

63. Carolyn M. Tilghman. "The Flesh Made Word: Luce Irigaray's rendering of the Sensible Transcendental." Janus Head 11 (2009): 39-54.

64. George Lakoff, and Mark Johnson. Metaphors We Live by. Chicago: The University of Chicago Press, 2003.

65. Peter Hershock. Chan Buddhism. Honolulu: University of Hawaii Press, 2005.

66. Gail Weiss. Refiguring the Ordinary. Bloomington: Indiana University Press, 2008.

67. David E. Klemm, and William Schweiker. Religion and the Human Future: An Essay on Theological Humanism. Malden: Wiley-Blackwell, 2008.

68. J. Aaron Simmons. God and the Other: Ethics and Politics after the Theological Turn. Bloomington: Indiana University Press, 2011.

69. Russell T. McCutcheon. Critics Not Caretakers: Redescribing the Public Study of Religion. New York: SUNY Press, 2001.

70. John Searle. Expression and Meaning: Studies in the Theory of Speech Acts. Cambridge: Cambridge University Press, 1979.

71. Paul Ricoeur. "Philosophy of Religious Language." The Journal of Religion 54 (1974): 71-85. [CrossRef]

72. Georg Wilhelm Friedrich Hegel. On Art, Religion, and the History of Philosophy: Introductory Lectures. Edited by J. Glenn Gray. Indianapolis: Hackett Publishing, 1997.

73. David Loy. "Zhuangzi and Nagarjuna on the Truth of No Truth." In Essays on Skepticism, Relativism, and Ethics in the Zhuangzi. Edited by Paul Kjellberg and Philip J. Ivanhoe. Albany: SUNY Press, 1996.

74. Plato. The Republic, 2nd ed. Translated by Alan Bloom. New York: Basic Books, 1991.

75. Anthony Bourdain, and Laurie Woolever. Appetites: A Cookbook. New York: ECCO, 2016.

76. Mircea Eliade. The Sacred and the Profane: The Nature of Religion. New York: Harcourt, 1987.

77. Charles Taylor. A Secular Age. Cambridge: Belknap Press, 2007.

78. Khaled Furani. "Is there a Postsecular? " Journal of the American Academy of Religion 83 (2015): 1-26. [CrossRef]

79. Ian Reader. Religion in Contemporary Japan. Honolulu: University of Hawaii Press, 1995.

80. Talal Asad. On Suicide Bombing. New York: Columbia University Press, 2007.

81. Judith Butler. Gender Trouble: Feminism and the Subversion of Identity. New York: Routledge, 1999.

82. Richard Polt. "A Heideggerian Critique of Cyberbeing." In Horizons of Authenticity in Phenomenology, Existentialism, and Moral Psychology. Edited by Hans Pedersen and Megan Altman. Dordrecht: Springer, 2015.

83. Yong Huang. "The Ethics of Difference in the Zhuangzi." Journal of American Academy of Religion 78 (2010): 65-99. [CrossRef]

84. Peta Hinton. “The Divine Horizon: Rethinking Political Community in Luce Irigaray's 'Divine Women'." Hypatia: A Journal of Feminist Philosophy 28 (2013): 436-51. [CrossRef]

85. Christian Helmut Wenzel. "Zhuangzi: Awareness, Freedom, and Autonomy." Journal of Chinese Philosophy 30 (2003): 115-26. [CrossRef]

86. Paul Ricoeur. "Religious Belief." In A Passion for the Possible. Edited by B. Treanor and H. Venema. New York: Fordham University Press, 2010.

87. Jennifer Michael Hecht. Doubt: A History: The Great Doubters and Their Legacy of Innovation from Socrates and Jesus to Thomas Jefferson and Emily Dickinson. New York: HarperOne, 2003.

88. Hans-Georg Gadamer. "The Artwork in Word and Image: 'So True, So Full of Being!'." In The Gadamer Reader: A Bouquet of Later Writings. Edited and Translated by Richard E. Palmer. Evanston: Northwestern University Press, 2007. 
89. Lee H. Yearley. “Zhuangzi's Understanding of Skillfulness and the Ultimate Spiritual State.” In Essays on Skepticism, Relativism, and Ethics in the Zhuangzi. Edited by Paul Kjellberg and Philip J. Ivanhoe. Albany: SUNY Press, 1996.

90. Soren Kierkegaard. Fear and Trembling/Repetition. Translated by Edna H. Hong and Howard V. Hong. Princeton: Princeton University Press, 1983.

91. Matsumoto Shiro. “The Doctrine of Tathagata-garbha Is Not Buddhist.” In Pruning the Bodhi Tree: The Storm over Critical Buddhism. Edited and Translated by Jamie Hubbard. Honolulu: University of Hawaii Press, 1997.

92. Thich Nhat Hanh. Beyond the Self: Teachings of the Middle Way. Berkeley: Parallax Press, 2010.

93. Linji. The Record of Linji. Translated by Ruth Fuller Sasaki. Honolulu: University of Hawaii Press, 2009.

94. Cheng Chein Bhikshu (Mario Poceski). Sun Face Buddha: The Teachings of Ma-Tsu and the Hung-Chou School of Ch'an. Freemont: Jain Publishing, 1992.

95. Mario Poceski. Ordinary Mind is the Way: The Hongzhou School and the Growth of Chan Buddhism. New York: Oxford University Press, 2007.

96. Dogen. Shobogenzo: The Treasure House of the Eye of True Teaching. Translated by Hubert Nearman. Mount Shasta: Shasta Abby Press, 2007.

97. Bernard Faure. Unmasking Buddhism. Oxford: Wiley-Blackwell, 2009.

98. Robert Scharf. "Buddhist Modernism and the Rhetoric of Meditative Experience." Numen 42 (1995): $228-83$. [CrossRef]

99. T. Griffith Foulk. "The Form and Function of Koan Literature: A Historical Perspective." In The Koan: Texts and Contexts in Zen Buddhism. Edited by Dale S. Wright and Steven Heine. Oxford: Oxford University Press, 2000.

100. Paul Tillich. The Courage to Be. New Haven: Yale University Press, 2000.

101. Herbert Fingarette. Confucius: The Secular as Sacred. Prospect Heights: Waveland Press, 1972.

(C) 2016 by the author; licensee MDPI, Basel, Switzerland. This article is an open access article distributed under the terms and conditions of the Creative Commons Attribution (CC-BY) license (http://creativecommons.org/licenses/by/4.0/). 